\title{
In vitro antibacterial activity of Loxostylis alata extracts and isolated compounds against Salmonella species
}

Dorcas A. Gado ${ }^{1,2}$, Muna Ali Abdalla ${ }^{1,3^{*}}$ D, Aroke S. Ahmed', Balungile Madikizela', Sanah M. Nkadimeng', Marthie M. Ehlers ${ }^{4,5}$ and Lyndy J. McGaw ${ }^{1}$

\begin{abstract}
Background: Owing to antibiotic resistance, alternative antimicrobials from medicinal plants are receiving attention as leads for anti-infective agents. This study aimed to investigate selected tree species and their constituents for activity against bacterial foodborne pathogens, particularly Salmonella serovars.

Methods: Antibacterial activity of ten plant species was determined by serial microdilution against bacteria implicated in causing gastrointestinal ailments. Active compounds were isolated from Loxostylis alata using bioassay-guided fractionation. Antioxidant activity was determined using free-radical scavenging assays. Cytotoxicity and genotoxicity of the extracts was ascertained on Vero cells, and using the Ames assay respectively.

Results: Extracts had low to moderate MIC values from 0.04 to $2.5 \mathrm{mg} / \mathrm{mL}$. Protorhus longifolia and Loxostylis alata were most active and L. alata had the highest selectivity index value (2.51) against Salmonella Typhimurium, as well as high antioxidant activity. Cytotoxicity values ranged from 0.02 to $0.47 \mathrm{mg} / \mathrm{mL}$, while tested extracts were not genotoxic. Bioactive compounds isolated from L. alata included delicaflavone and a polymethoxyflavone.

Conclusions: The Loxostylis alata leaf extract had strong activity against Salmonella serovars but isolated compounds were less active, indicating likely synergistic effects. Extracts of L. alata are promising candidates for development of antimicrobial preparations or food additives against microbial contamination.
\end{abstract}

Keywords: Antimicrobial, Salmonella, Cytotoxicity, Loxostylis alata, Biflavonoid

\section{Background}

Microbial safety of food is a major concern to consumers, regulatory agencies and food industries throughout the world [1]. About 600 million people globally suffer from ill health due to consumption of contaminated food, and about 420,000 deaths are recorded annually (WHO, 2018a). Foodborne diseases of bacterial aetiology are commonly caused by enterohaemorrhagic

\footnotetext{
* Correspondence: munalsamahoni@yahoo.com

'Phytomedicine Programme, Department of Paraclinical Sciences, University of Pretoria, Private Bag X04, Onderstepoort 0110, Pretoria, South Africa ${ }^{3}$ Department of Food Science and Technology, Faculty of Agriculture, University of Khartoum, 13314 Khartoum North, Sudan

Full list of author information is available at the end of the article
}

Escherichia coli as well as Campylobacter and Salmonella species [2]. Salmonella species are considered second only to Campylobacter as a major cause of gastrointestinal infections in companion animals, livestock and humans, particularly in developing countries [3]. Salmonella contamination and resultant infection has a high economic burden in food production, due to a very broad host range and significant morbidity and mortality in the human population $[4,5]$. Presently, over 2500 Salmonella serovars have been characterized but only a few (approximately 150) cause salmonellosis in humans and domestic animals, and all motile serovars are reported as zoonotic [6]. Salmonella enterica subsp.

(c) The Author(s). 2021 Open Access This article is licensed under a Creative Commons Attribution 4.0 International License, which permits use, sharing, adaptation, distribution and reproduction in any medium or format, as long as you give appropriate credit to the original author(s) and the source, provide a link to the Creative Commons licence, and indicate if changes were made. The images or other third party material in this article are included in the article's Creative Commons licence, unless indicated otherwise in a credit line to the material. If material is not included in the article's Creative Commons licence and your intended use is not permitted by statutory regulation or exceeds the permitted use, you will need to obtain permission directly from the copyright holder. To view a copy of this licence, visit http://creativecommons.org/licenses/by/4.0/ The Creative Commons Public Domain Dedication waiver (http://creativecommons.org/publicdomain/zero/1.0/) applies to the data made available in this article, unless otherwise stated in a credit line to the data. 
enterica serotype Typhimurium (Salmonella Typhimurium) and Salmonella Enteritidis are the most common causes of human infection [7]. In 2015 alone, invasive non-typhoidal Salmonella (iNTS) disease was estimated to cause 680,000 deaths per year worldwide, more than half of which were in Africa [8]. Therefore, Salmonella control will continue to be a major task at all stages of the food chain from production through to processing, distribution and consumption, to decrease the incidence of food contamination and to ensure food safety [9].

Gastroenteritis is mostly treated with a wide range of antibiotics, usually administered at reduced or prophylactic levels to enhance performance and prevent infection in animals [10-12]. The indiscriminate use of antibiotics as prophylaxis and growth enhancers in animal production is reported to have contributed to the current global challenge of emergence of drug-resistant and multidrug-resistant strains of bacteria, threatening global health and food security [13, 14]. Humans acquire resistant serovars from food or animals, and subsequent transmission occurs from human to human [15]. Resistance to antibiotics complicates treatment through higher treatment costs and increased mortality [16], especially in immunocompromised individuals. These undesired consequences of antibiotic resistance, coupled with the absence of effective oral vaccines protecting against salmonellosis, have resulted in consumers demanding safe, high-quality foods and hence researchers have been searching for alternative methods to control enteric infections $[17,18]$. It has therefore become imperative to search for novel antimicrobials effective against resistant pathogens, or alternatively, immune modulators or other biologics to combat pathogens [19-23].

As bacteria continue to evolve, there is growing global attention towards exploring the natural world for secondary metabolites as potential sources for drug development [22]. Several drugs have been developed over time from natural products [24-26]. Plant extracts contain mixtures of secondary metabolites such as alkaloids, coumarins, flavonoids, glycosides, phenols, quinones, saponins, steroids, tannins and terpenoids [27, 28]. Each of these metabolites may possess individual bioactivity or may act together in synergy to disrupt the growth or pathogenesis of disease-causing organisms [29]. Polyphenolic compounds are major constituents of medicinal plants reported to act as free radical scavengers and antioxidants [30, 31].

In this study, selected South African plant species known to have good efficacy against Gram-negative Escherichia coli [32] were screened for antibacterial activity against strains implicated in foodborne diseases as a lead to identifying extract(s) or compound(s) active against Salmonella species. Plant extracts with good antimicrobial activity were evaluated for genotoxicity and cytotoxicity, and antioxidant activity, which is an additional beneficial property of medicinal plants. The use of active plant components as natural additives has gained increasing interest in the food and health industries, with recent studies promoting the possibility of using these antioxidant and antimicrobial constituents as food preservatives, or functional food ingredients [33, 34]. Owing to promising preliminary activity (good antimicrobial activity, relative safety and good antioxidant activity), extracts of $L$. alata were further investigated for their antibacterial activity against commercially available Salmonella enterica serovar Typhimurium (ATCC 14028), and S. Enteritidis (ATCC 13076) as well as field isolates of $S$. Typhimurium, $S$. Dublin and $S$. Braenderup, with the aim of isolating compounds active against Salmonella serovars.

\section{Methods}

Plant collection and sample preparation

Leaves of Blighia unijugata, Carissa macrocarpa, Combretum bracteosum, Kirkia wilmsii, Loxostylis alata, Noltea africana and Protorhus longifolia were collected at the Manie van der Schijff Botanical Garden of the University of Pretoria, South Africa. Brachychiton acerifolium, Brachychiton bidwillii and Searsia leptodictya were collected at the Onderstepoort campus, Faculty of Veterinary Science, University of Pretoria, South Africa. All plants used in this study were collected in summer months of 2016. Voucher specimens of the plants were identified and deposited at the H.G.W.J. Schweickerdt Herbarium of the Department of Plant and Soil Sciences, University of Pretoria, South Africa. Leaves of plants collected were thoroughly cleaned and air-dried in a drying room away from direct sunlight, at the Department of Paraclinical Sciences, University of Pretoria. Thereafter, dried plants were ground to a fine powder in a Macsalab mill [(Model 200 LAB), Eriez, South Africa] and stored in closed containers in the dark until used.

\section{Preparation of plant extracts for in vitro biological assays}

Powdered leaf material $(10 \mathrm{~g})$ of each plant was extracted separately by adding $100 \mathrm{~mL}$ each of acetone, methanol, ethanol (Minema, South Africa), cold and hot (boiling temperature) distilled water to obtain the respective crude extracts. The plant material in the extraction solvents was left to stand for $24 \mathrm{~h}$ and filtered through Whatman No. 1 filter paper (Merck, United States). The resultant extracts were transferred into pre-weighed labelled glass jars and the extraction procedure described above was repeated twice on the same plant material for exhaustive extraction. Pooled extracts were placed under a stream of air to dry completely and stored in the dark at $4{ }^{\circ} \mathrm{C}$ until needed for experiments.

Bulk extraction was carried out for compound isolation. Ground leaf material of Loxostylis alata $(250 \mathrm{~g})$ was extracted with $100 \%$ methanol (ratio 1:10) and extraction 
was repeated twice on the same plant material. The solvent of the combined extracts was removed in vacuo after filtration. The dried methanol extract ( $28 \mathrm{~g}$ ) was subjected to solvent-solvent fractionation using solvents of different polarity: hexane, chloroform, ethyl acetate, butanol (Minema, South Africa) and water (Fig. 1).

\section{Antimicrobial screening Microbial strains}

Five of the bacterial species used in this study were obtained from the American Type Culture collection (ATCC) and consisted of Gram-positive strains: Bacillus cereus (ATCC 21366), Enterococcus faecalis (ATCC
29212) and Staphylococcus aureus (ATCC 29213), and Gram-negative strains: Pseudomonas aeruginosa (ATCC 27853) and Salmonella Typhimurium (ATCC 700720). The other bacteria were Gram-negative clinical isolates from eggs (Jambalang et al., 2017) and included Enterobacter cloacae, Escherichia coli, Klebsiella pneumoniae, Proteus mirabilis and Stenotrophomonas maltophilia obtained from the Phytomedicine Repository at the University of Pretoria.

For further evaluation of L. alata, two strains from the American Type Culture Collection, Salmonella Typhimurium (ATCC 14028) and S. Enteritidis (ATCC 13076), and local isolates of $S$. Dublin, $S$. Braenderup and

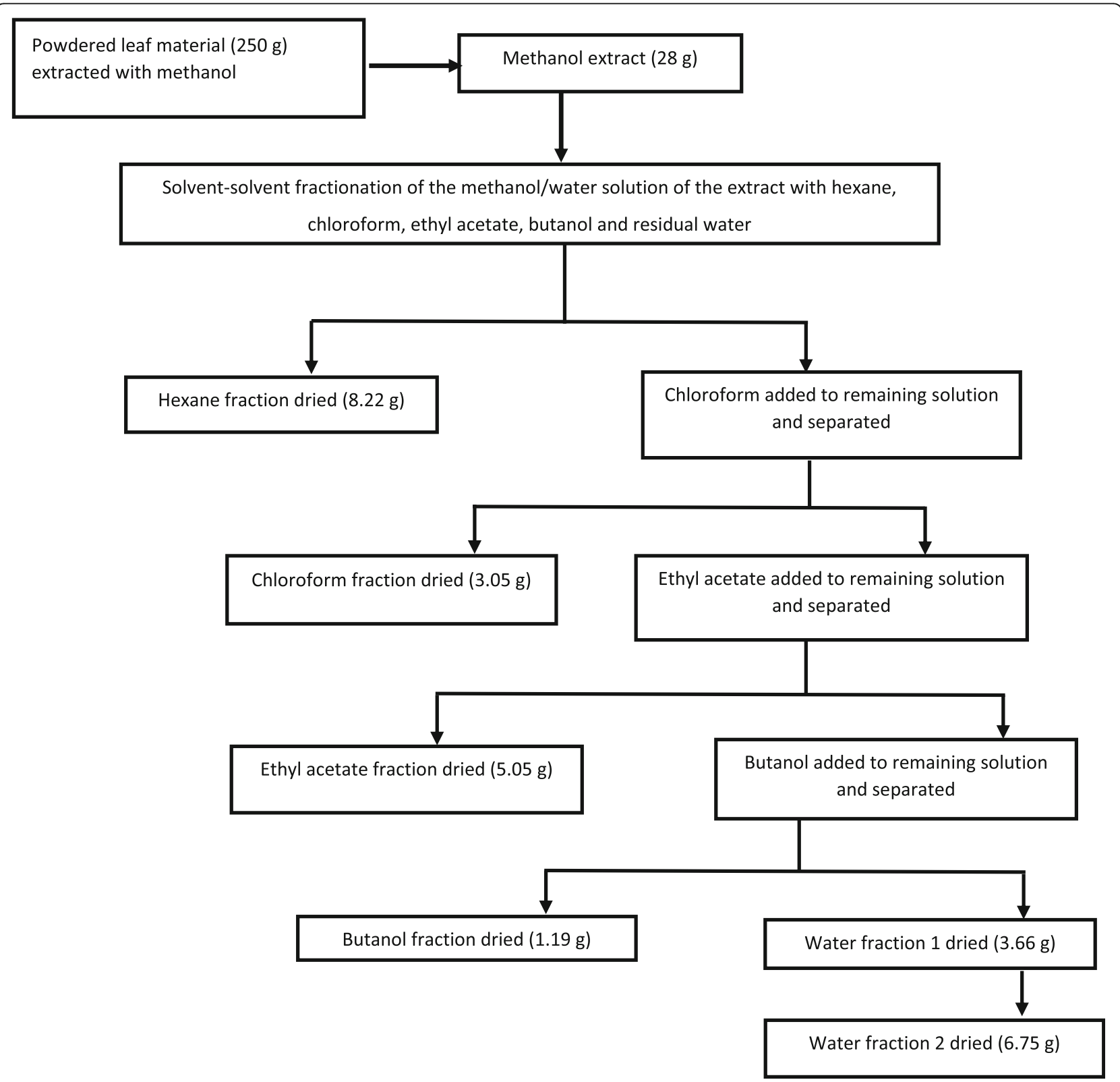

Fig. 1 Procedure for solvent-solvent fractionation of methanol leaf extract of Loxostylis alata 
S. Typhimurium provided by the Phytomedicine Programme, University of Pretoria [35] were included.

\section{Culturing microbial strains}

All bacterial strains were plated from cultures which were stored at $-80^{\circ} \mathrm{C}$ on ceramic beads in cryoprotective media (Pro-Lab diagnostics Microbank ${ }^{@} 20$ ) onto Müller-Hinton (MH) agar (Merck, South Africa) except for the Salmonella species which were plated unto xylose lysine deoxycholate (XLD-Merck, South Africa) and grown for $18-24 \mathrm{~h}$ (IncoTherm; Labotec) at $37^{\circ} \mathrm{C}$. Cultures were subsequently sub-cultured and maintained on $\mathrm{MH}$ agar plates at $4{ }^{\circ} \mathrm{C}$ until needed for further antimicrobial testing.

\section{In vitro antibacterial assay}

The minimum inhibitory concentration (MIC) values of the plant extracts against different bacterial species were determined using a serial microdilution assay [36]. All bacterial isolates screened were prepared by inoculating a single colony from an agar plate into $10 \mathrm{~mL}$ of sterilized $\mathrm{MH}$ broth (Merck, South Africa) and incubated at $37^{\circ} \mathrm{C}$ in an MRC orbital shaker (150 rpm) incubator (United Scientific, South Africa) for 18 to $20 \mathrm{~h}$ prior to the experiment. Following incubation, each bacterial strain was diluted in $\mathrm{MH}$ broth (Merck, South Africa) and the absorbance was measured at a wavelength of $560 \mathrm{~nm}$ using a spectrophotometer (Epoch microplate reader: BioTek, United States). Absorbance was adjusted to match that of a McFarland standard No 1 (correlating to approximately $3 \times 10^{8}$ colony forming units $(\mathrm{cfu}) / \mathrm{mL}$ ). Sterile distilled water $(100 \mu \mathrm{L})$ was added to each well of a 96-well microtitre plate (Lasec, South Africa). Plant extracts were re-constituted to $10 \mathrm{mg} / \mathrm{mL}$ in sterile distilled water for the water extracts and $70 \%$ acetone for the organic solvent extracts. Aliquots $(100 \mu \mathrm{L})$ of each extract were added to the first well (row A) of the 96well microtitre plates, and serially diluted two-fold down the wells to row $\mathrm{H}$ and the last $100 \mu \mathrm{L}$ discarded. Gentamicin (Virbac, South Africa) and tetracycline (Sigma-Aldrich, United States) at an initial concentration of $2 \mathrm{mg} /$ $\mathrm{mL}$ were used as positive controls, while acetone, sterile distilled water and bacterial cultures were used as negative and untreated controls. Subsequently, $100 \mu \mathrm{L}$ of each diluted bacterial culture were added to all wells of the microtitre plates. The microtitre plates were incubated at $37^{\circ} \mathrm{C}$ for 18 to $24 \mathrm{~h}$ (IncoTherm, Labotec). After incubation, $40 \mu \mathrm{L}$ of $0.2 \mathrm{mg} / \mathrm{mL}$ p-iodonitrotetrazolium (INT) (Sigma-Aldrich, United States) were added to each well to determine the MIC and the microtitre plates were re-incubated at $37^{\circ} \mathrm{C}$ for $1 \mathrm{~h}$. Bacterial cultures react with INT and give a red or purple colouration within 10 to $60 \mathrm{~min}$ [36]. The last clear well was taken as the MIC, i.e. where bacterial growth was inhibited, the solution in the well remained clear or had a decreased colour change after incubation with INT. The experiment was repeated twice with three replicates in each assay. Besides determining the MIC for each plant extract, the total activity was calculated as "the total mass in mg extracted from $1 \mathrm{~g}$ of plant material divided by the MIC value $(\mathrm{mg} / \mathrm{mL})$ ". The total activity expressed in $\mathrm{mL} / \mathrm{g}$ indicates "the volume to which the extract derived from $1 \mathrm{~g}$ of plant material can be diluted and still inhibit the growth of the microorganism" [37, 38].

\section{Antioxidant assays}

The ABTS [2, 2-azino-bis- (3-ethylbenzothiazoline-6-sulfonic acid)] assay

The ABTS antioxidant assay was conducting following the described method [39], with Trolox, a synthetic water soluble vitamin $\mathrm{E}$ analogue, and ascorbic acid (Adminide, South Africa) serving as positive controls. The negative control was $100 \%$ methanol (Minema, South Africa), and extracts without ABTS served as blanks [38]. The percentage of $\mathrm{ABTS}^{+}$inhibition was calculated using the following formula:

$$
\text { Scavenging capacity }(\%)=100-\left[\frac{\mathrm{Abs}(\text { sample })-\mathrm{Abs}(\text { sample blank })}{\mathrm{Abs}(\text { control })-\mathrm{Abs}(\text { control blank })} \times 100\right]
$$

$\mathrm{IC}_{50}$ values were calculated from the graph plotted as percentage inhibition against the concentration [38].

\section{The DPPH (2, 2'-diphenyl-1-picrylhydrazyl) assay}

The DPPH assay was conducted according to the method described by [40] with ascorbic acid and Trolox as positive controls. Methanol (100\%) was used as a negative control and extracts without DPPH (2, 2'diphenyl-1-picrylhydrazyl) served as blanks. Results were expressed as the concentration of extract that reduced the $\mathrm{DPPH}$ colour by $50 \%\left(\mathrm{IC}_{50}\right)$, which was determined as for the ABTS assay [38].

\section{Toxicological assays \\ In vitro cytotoxicity}

The MTT (3-(4, 5-dimethylthiazolyl-2)-2.5-diphenyltetrazolium bromide) reduction assay was used to measure cell proliferation and cytotoxicity of plant extracts against African green monkey kidney (Vero) cells (ATCC ${ }^{\circ}$ CCL-81 ${ }^{\mathrm{m}}$, Sigma-Aldrich, United States). The viable cell growth after incubation with test plant extracts was determined using the tetrazolium-based colorimetric assay (MTT assay) [41] with some modification [42]. Vero cells were grown in sterile Minimal Essential Medium (MEM) (Sigma-Aldrich, United States) supplemented with $0.1 \%$ gentamicin (Virbac, South Africa) and 5\% foetal calf serum (FCS) (Highveld Biological, South Africa) in a $75 \mathrm{~cm}^{2}$ flask (Whitehead Scientific, South Africa), and incubated at $37^{\circ} \mathrm{C}$ in $5 \%$ 
$\mathrm{CO}_{2}$ (Hera Cell 150, ThermoScientific Germany). When cells had grown to confluency, they were harvested using trypsin/ethylenediamine tetraacetic acid (EDTA) solution (Invitrogen, Cergy-Pontoise, France), centrifuged (Universal 320R, Labotech South Africa) for $5 \mathrm{~min}$ at $200 \times$ g, counted using a Neubauer haemocytometer, and re-suspended in MEM. The cells were seeded in a 96well cell culture grade microtitre plate (Whitehead Scientific, South Africa) at a final concentration of 10,000 cells per well. The plates were incubated at $37^{\circ} \mathrm{C}$ in $5 \%$ $\mathrm{CO}_{2}$ overnight to allow proper attachment of cells and to enable cells to reach exponential growth phase.

A stock concentration of $100 \mathrm{mg} / \mathrm{mL}$ of the plant extract was prepared, from which different concentrations were prepared in serum-free MEM ranging from 0.0075 to $1 \mathrm{mg} / \mathrm{mL}$, and the cells were treated in triplicate. Doxorubicin hydrochloride (Pfizer Laboratories, South Africa) was used as a positive control, whereas untreated cells and 1\% dimethyl sulphoxide (DMSO) were used as negative controls. The plates were incubated at $37^{\circ} \mathrm{C}$ in $5 \% \mathrm{CO}_{2}$ environment (Hera Cell 150, ThermoScientific Germany) for $48 \mathrm{~h}$. After the $48 \mathrm{~h}$ incubation period, the medium was aspirated from the wells, and the cells were washed with $200 \mu \mathrm{L}$ of phosphate buffered saline (PBS) pH 7.4 (Whitehead Scientific, South Africa). Fresh MEM $(100 \mu \mathrm{L})$ and $30 \mu \mathrm{L}$ of MTT $(5 \mathrm{mg} / \mathrm{mL}$ stock solution: Sigma-Aldrich, South Africa) dissolved in PBS were added to all the wells and the plates were incubated at $37^{\circ} \mathrm{C}$ in $5 \% \mathrm{CO}_{2}$ for $4 \mathrm{~h}$. Following incubation, the media with MTT was removed, $50 \mu \mathrm{L}$ of DMSO (BDH, South Africa) were added to each well, and the plates were shaken gently (QG-9001 microporous Quickshaker, Hinotek; China) until the crystals were dissolved. The amount of MTT reduction was measured using a spectrophotometer (Biotek Synergy, USA) at a wavelength of $570 \mathrm{~nm}$ (reference wavelength of $630 \mathrm{~nm}$ ). The wells in column 1, containing medium (MEM) and MTT but no cells were used as blanks. The results were interpreted as percentage of the control wells, and lethal concentration $\left(\mathrm{LC}_{50}\right)$ values calculated as the concentration of plant samples resulting in a $50 \%$ reduction of absorbance after $48 \mathrm{~h}$ incubation (that is $50 \%$ of the cells were killed) compared to untreated cells. The selectivity index values for each extract were calculated from the MIC values of the extracts against tested bacterial strains and $\mathrm{LC}_{50}$ values, using the following formula: $\mathrm{SI}=\mathrm{LC}_{50} / \mathrm{MIC}$.

\section{In vitro genotoxicity assay}

In this study, extracts that showed MIC values less than $1 \mathrm{mg} / \mathrm{mL}$ against at least three bacterial strains were tested for genotoxicity. The Salmonella microsome assay according to Maron and Ames (1983) and modified by Mortelmans and Zeiger (2000) was used to determine the genotoxicity of selected extracts. Two Salmonella typhimurium tester strains, TA98 and TA100 which indicate frame-shift and base pair mutations respectively, were used for the assay which was done without metabolic activation. Briefly, crude plant extract was dissolved in $10 \%$ DMSO (BDH, South Africa) and diluted to yield final concentrations of 5, 0.5 and $0.05 \mathrm{mg} / \mathrm{mL}$. Approximately $1 \times 10^{8} \mathrm{CFU}$ stock bacterial cultures $(100 \mu \mathrm{L})$ incubated in nutrient broth No. 2 (Sigma-Aldrich, South Africa) on a MRC orbital shaker $(150 \mathrm{rpm})$ incubator (United Scientific, South Africa) at $37^{\circ} \mathrm{C}$ for $16 \mathrm{~h}$, were added to test samples $(100 \mu \mathrm{L})$ followed by $500 \mu \mathrm{L}$ of pH 7.4 PBS (Whitehead Scientific, South Africa) and 2 $\mathrm{mL}$ of top agar containing biotin/histidine $(0.5 \mathrm{mM})$. A positive control, 4-nitroquinoline-1-oxide [(4-NQO) (Sigma-Aldrich, South Africa)] at a concentration of $2 \mu \mathrm{g} / \mathrm{mL}$ was used, and two negative controls, sterile distilled water and $10 \%$ DMSO (BDH, South Africa), were used. The mixture was vortexed (VM-300 vortex mixer, Gemmy; Taiwan), and poured on minimal agar plates (Sigma-Aldrich, South Africa) and incubated (IncoTherm; Labotec) for $48 \mathrm{~h}$ at $37^{\circ} \mathrm{C}$. Each sample was tested in triplicate for each concentration and the experiment was repeated 3 times. After $48 \mathrm{~h}$ of incubation (IncoTherm; Labotec) at $37^{\circ} \mathrm{C}$, revertant (mutant) colonies were counted. An extract is considered mutagenic when the mean number of revertants is equal to or more than double that found in the negative control $[43,44]$.

\section{Statistical analysis}

Data are presented as mean \pm standard error of mean. Differences in the means were subjected to post-hoc analysis using the Tukey's test. The IBM SPSS software package version 25.0.0 was used for the statistical tests. Differences were considered significant at $p<0.05$.

\section{Isolation of compounds}

The dried methanol extract $(28 \mathrm{~g})$ was dissolved in a mixture of hexane and water and fractionated by solvent-solvent extraction (Fig. 1) to yield hexane (8.22 $\mathrm{g})$, chloroform $(3.05 \mathrm{~g})$, ethyl acetate $(5.05 \mathrm{~g})$, butanol $(1.19 \mathrm{~g})$, water $1(3.66 \mathrm{~g})$ and water $2(6.75 \mathrm{~g})$ fractions after drying. The organic solvent fractions were evaporated to dryness under reduced pressure at low temperature $\left(40\right.$ to $50^{\circ} \mathrm{C}$ ) in a rotary evaporator (Buchi Rotavapor R-200, Switzerland). The water fraction was dried by vaporisation in an oven at $60^{\circ} \mathrm{C}$.

The ethyl acetate fraction had the best antimicrobial activity against the Salmonella serovars used in this study and was therefore chosen for further isolation of active compounds. Column chromatography (CC) with silica gel 60 (Sigma-Aldrich, South Africa) was carried out to fractionate the ethyl acetate fraction $(5.05 \mathrm{~g})$ using a combination of chloroform: methanol: formic acid (90: 10:2) (Minema, South Africa). Fractions with similar 
appearance and Rf values on TLC plates (Merck, United States) when viewed on a universal UV lamp (CAMAG TL-900/U, Switzerland), were pooled to obtain seven fractions (FI to FVII). Silica gel CC was further used to run the FII fraction using the same solvent combination but this time at a ratio of 95:5:2 and this yielded two pure whitish compounds (samples 1 and 2). The FI, FIII to FVII fractions were further combined and a chloroform: methanol step gradient Silica gel CC ran: starting with $100 \%$ chloroform and then reduced to $0 \%$ chloroform by the addition of methanol in successive steps, i.e. $\mathrm{CHCl}_{3}: \mathrm{MeOH}(100: 0,99: 1,97: 3,95: 5,93: 7,93: 10,87: 13$ and 85:15). Fractions with a similar appearance on TLC plates were pooled to obtain eight fractions (F1-8). The F7 fraction was a pure whitish yellow compound (sample 3 ). The F6 fraction was only partially soluble in methanol and was filtered using Whatman No.1 filter paper. The filtrate (methanol-soluble) was yellowish in solution while the residue/precipitate (acetone soluble) was dirty white in colour (sample 4). The filtrate was centrifuged (EBA 20, Labotec; South Africa) for $5 \mathrm{~min}$ at $3000 \mathrm{x}$ g to obtain a clear supernatant and sediment. The supernatant was further fractionated by Sephadex LH-20 (Sigma-Aldrich, South Africa) column chromatography eluted isocratically with methanol to give a yellowish powder (sample 5).

\section{Structure identification of the isolated compounds}

Compound detection was performed using a Waters ${ }^{\circ}$ Synapt G2 high definition mass spectrometry (HDMS) system (Waters Inc., Milford, Massachusetts, USA). Samples were analysed using flow injection analysis (FIA). The system comprises of a Waters Acquity Ultra Performance Liquid Chromatography (UPLC) system hyphenated to a quadrupole-time-of-flight (QTOF) instrument. The system was operated with MassLynxTM (version 4.1) software (Waters Inc., Milford, Massachusetts, USA) for data acquisition and processing. Nuclear magnetic resonance (NMR) (1D and 2D) spectroscopy was also carried out. Proton nuclear magnetic resonance $\left({ }^{1} \mathrm{H}\right.$ NMR $)$ and two-dimensional nuclear magnetic resonance (2D NMR) data were acquired on a $400 \mathrm{MHz}$ NMR spectrometer (Bruker Avance III $400 \mathrm{MHz}$ ). Structures of isolated compounds were confirmed by comparison of their NMR data with those published previously.

Samples not detected as pure compounds by NMR were subjected to gas chromatography coupled to a mass spectrometer (GC-MS) using a LECO Pegasus 4D GCTOFMS (LECO Africa (Pty) Ltd., Kempton Park, South Africa). The GC column was a Rxi-5SilMS $30 \mathrm{~m} \times 0.25$ $\mathrm{mm}$ ID $\times 0.2 \mu \mathrm{m}$ film thickness (Restek, Bellefonte, PA, USA). The injector port was maintained at $250{ }^{\circ} \mathrm{C}$; the oven temperature was programmed at $40^{\circ} \mathrm{C}$ (hold for 3 min) to $300^{\circ} \mathrm{C}$ (hold for $5 \mathrm{~min}$ ). The carrier gas was helium (helium UHP, Afrox, Gauteng, South Africa) and the velocity of the gas was at $1 \mathrm{~mL} / \mathrm{min}$ in the constant flow mode. The MS transfer line was set to $280^{\circ} \mathrm{C}$, and the ion source temperature was $230^{\circ} \mathrm{C}$. The electron energy was $70 \mathrm{eV}$ in the electron impact ionization mode, the mass acquisition range was from 40 to $550 \mathrm{Da}$, the detector voltage was held at $1750 \mathrm{~V}$. Data acquisition at a rate of $10 \mathrm{spectra} / \mathrm{s}$ was done.

\section{Results}

\section{Antibacterial activity}

The botanical names of the plants, voucher reference numbers, and traditional uses and parts used are presented in Table 1. The results of the antibacterial assay of the fifty extracts from ten plant species against five ATCC bacterial strains and five clinical isolates are presented as MIC values in Table 2. MIC values of the extracts ranged from 0.04 to $2.5 \mathrm{mg} / \mathrm{mL}$ against all strains tested. The best MIC value of 0.04 $\mathrm{mg} / \mathrm{mL}$ was observed with several extracts and others had good MIC values of $0.08 \mathrm{mg} / \mathrm{mL}$. Overall for the crude extracts, the lowest sensitivity was obtained for S. Enteritidis (ATCC 13076) with a mean MIC value of $0.31 \mathrm{mg} / \mathrm{mL}$.

MIC values ranging from 0.04 to $2.5 \mathrm{mg} / \mathrm{mL}$ (Table 3) were observed with further testing of extracts of $L$. alata against the Salmonella species: Salmonella Typhimurium (ATCC 14028), S. Enteritidis (ATCC 13076), S. Dublin, S. Braenderup and S. Typhimurium. The best bacterial inhibition was observed with $\mathrm{MIC}=0.04 \mathrm{mg} /$ $\mathrm{mL}$ by the methanol crude extract of $L$. alata against $S$. Braenderup (a field isolate from chicken eggs). In ethnopharmacological studies, the quantity extracted from each plant species is as important as the MIC values. Both values were relevant for the determination of the Total Activity (TA). The total activity of the plants ranged from 256.14 to $10,051.28 \mathrm{~mL} / \mathrm{g}$ (Table 3) for the Salmonella serotypes screened in this study. The highest total activity of $10,051.28 \mathrm{~mL} / \mathrm{g}$ was produced by the methanol extract of $L$. alata against $S$. Braenderup. This implies that $1 \mathrm{~g}$ of $L$. alata methanol extract can be diluted in 10,051.28 mL of the solvent used and still inhibit the growth of the bacterium. Considering the average total activity for all extracts, the methanol extract had the best value (Fig. 2) and hence methanol extracts of the selected plant species were used for further assays.

MIC values of the fractions of $L$. alata are presented in Table 4. The MIC values obtained after solventsolvent fractionation of L. alata ranged from 0.04 to $1.25 \mathrm{mg} / \mathrm{mL}$ with the ethyl acetate and butanol fractions having the lowest mean MIC values against the Salmonella serovars screened (Table 4). 
Table 1 Botanical name, family and voucher specimen number of each plant species used in this study

\begin{tabular}{llll}
\hline Family & Plant species & Common name & Voucher specimen number \\
\hline Anacardiaceae & Loxostylis alata A. Spreng. ex Rchb & Tarwood & PRU 124357 \\
Anacardiaceae & Protorhus longifolia Bernh. (Engl.) & Red Beech & PRU 122537 \\
Anacardiaceae & Searsia leptodictya (Diels) T.S.Yi, A.J.Mill. \& J.Wen & Mountain & PRU 122531 \\
& & karee & PRU 122534 \\
Apocynaceae & Carissa macrocarpa (Eckl.) A.DC. & Big Num Num & PRU 117443 \\
Combretaceae & Combretum bracteosum (Hochst.) Engl. \& Diels & Hiccup nut & PRU 122536 \\
Kirkiaceae & Kirkia wilmsii Engl: & Wild pepper & PRU 122529 \\
Malvaceae & Brachychiton acerifolium (A. Cunn. ex G.Don) F.Muell & Flame tree & PRU 122530 \\
Malvaceae & Brachychiton bidwillii Hook. & Dwarf kurrajong & PRU 122535 \\
Rhamnaceae & Noltea africana (L.) Rchb. f. & Soap bush & PRU 122548 \\
Sapindaceae & Blighia unijugata Baker & Triangle-tops &
\end{tabular}

\section{Antioxidant activity, cytotoxicity and genotoxicity}

Almost all the tested extracts had moderate to potent antioxidant activity in both assays (Table 5). Methanol extracts had the highest average total activity compared to other extractants (Fig. 2), and as such were selected for cytotoxicity investigation against Vero monkey kidney cells. Table 6 shows the results for cytotoxicity of crude extracts represented as $\mathrm{LC}_{50}$ values, and their respective selectivity index (SI) values where $\mathrm{SI}=\mathrm{LC}_{50} /$ MIC. LC $_{50}$ values $>0.1 \mathrm{mg} / \mathrm{mL}$ are considered noncytotoxic [45]. $\mathrm{LC}_{50}$ values of the ten screened extracts ranged from 0.02 to $0.47 \mathrm{mg} / \mathrm{mL}$, while the selectivity index values ranged from 0.03 to 8.05 .

As this study primarily sought plant species with good activity against Salmonella species, only plants with at least one extract having an MIC value of less than 0.1 $\mathrm{mg} / \mathrm{mL}$ against $S$. Typhimurium were selected for genotoxicity testing. Hence, K. wilmsii, L. alata, P. longifolia and $S$. leptodictya were chosen. The results of the Ames assay for genotoxicity determine if any of the plant extracts had the ability to mutate genes and are presented in Table 7. None of the extracts was genotoxic at the concentrations tested.

Isolation of compounds from L. alata with activity against Salmonella species

Compound 1 (sample 4) was isolated as a whitish amorphous powder and identified by comparing spectroscopic data in available literature as the biflavone compound delicaflavone (3-[4-(5,7-dihydroxy-4-oxo-4H-1benzopyran-2-yl) phenoxy]-5,7-dihydroxy-2-(4-hydroxyphenyl)-4H-1-benzopyran-4-one) (Fig. 3). Compound 2 (sample 2) was isolated as a whitish amorphous powder and was identified as 5-hydroxy-4',5',6,7-tetramethoxyflavone (5-demethyl sinensetin) (2) (Fig. 3). Table 8 shows the MIC values obtained for the isolated compounds against the Salmonella ATCC strains.
Compounds 2 and 3 had the highest MIC values $(0.37$ $\mathrm{mg} / \mathrm{mL})$ followed by compounds 1 and $4(0.25 \mathrm{mg} / \mathrm{mL})$.

The remaining samples were not entirely pure and as such they were subjected to GC-MS for identification of their constituents. Table 9 shows the top three chemical constituents with the highest area percentage (>1\%) and over $90 \%$ similarity in each sample. The mixtures in samples 3 and 4 were both majorly composed of benzoic acid 3, 4, 5-trihydroxy methyl ester at area percentage values of 39 and $43 \%$ respectively. The percentage similarity for both was above $90 \%$, and hence this is a very close match to the reference compound. The GC-MS result for the mixture in sample 5, identified the major constituent as cetene with an area $\%=22 \%$ (Table 9).

\section{Discussion}

Antibacterial activity

A proposed measure suggests that MIC values less than $0.1 \mathrm{mg} / \mathrm{mL}$ are considered as good antimicrobial activity; MIC of 0.1 to $0.5 \mathrm{mg} / \mathrm{mL}$ is moderate antimicrobial activity while MIC of 0.5 to $1 \mathrm{mg} / \mathrm{mL}$ is weak antimicrobial activity and MIC of greater than $1 \mathrm{mg} / \mathrm{mL}$ is considered inactive [46]. The extracts of $L$. alata and $P$. longifolia had promising results with good $(\mathrm{MIC}<0.1 \mathrm{mg} / \mathrm{mL})$ antibacterial activity in at least three out of the five extracts tested and growth inhibition of at least eight out of the ten $(80 \%)$ bacteria screened. The results in this study confirm the good antibacterial activity of L. alata as reported in a previous study, where extracts of this plant had MIC values as low as $0.08 \mathrm{mg} / \mathrm{ml}$ against some bacteria including E. coli [47]. The significant activity (MIC value between 0.04 and $0.08 \mathrm{mg} / \mathrm{mL}$ ) against $E$. coli obtained for the acetone extracts of $B$. bidwillii, $B$. unijugata, K. wilmsii, L. alata, N. africana and P. longifolia is noteworthy. It should be kept in mind that antibacterial activity in vivo may also be attributed to specific enzyme activation, immunomodulation or 
Table 2 Minimal inhibitory concentration (MIC in mg/mL) of the leaf extracts from ten plants screened against ten bacterial strains

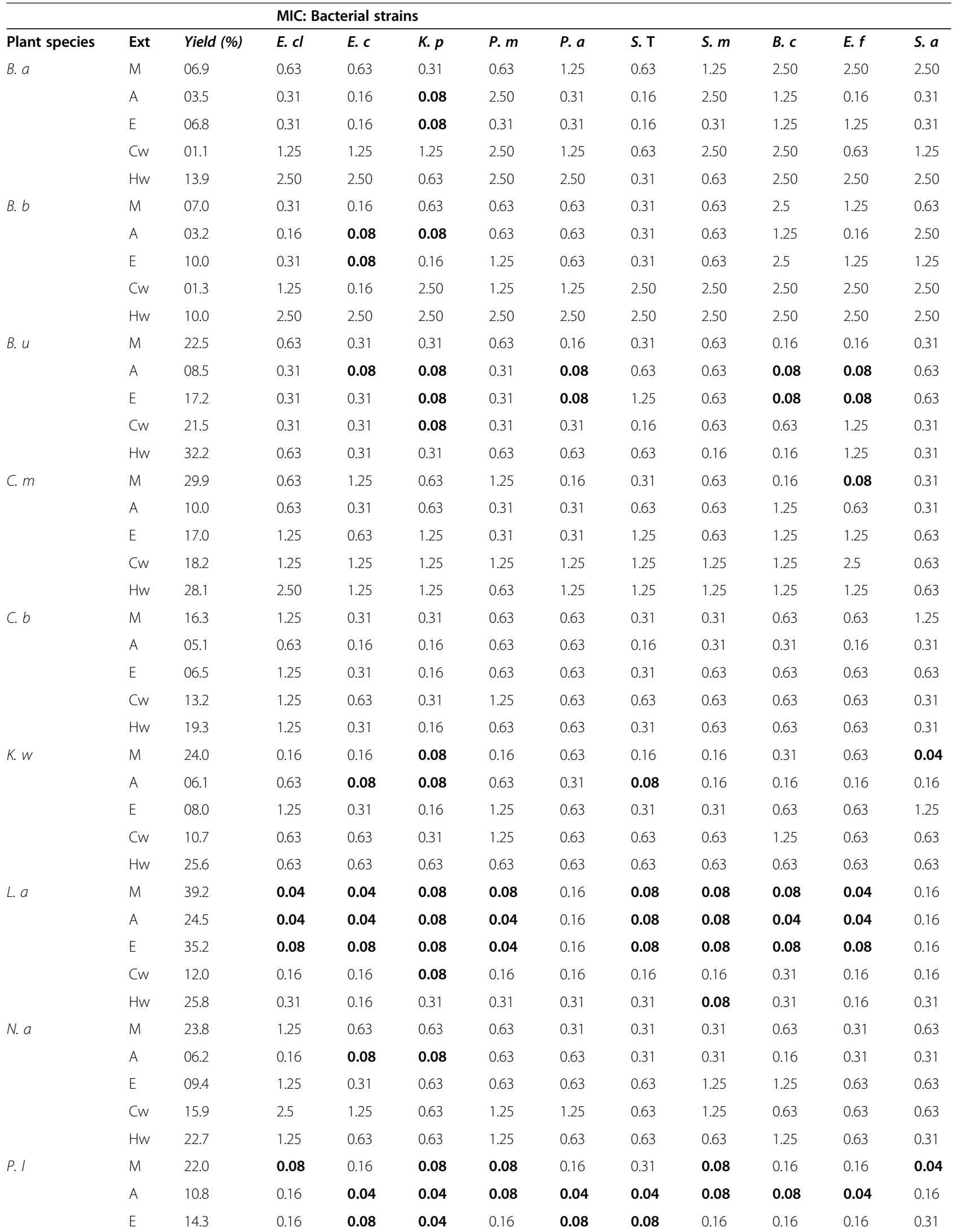


Table 2 Minimal inhibitory concentration (MIC in $\mathrm{mg} / \mathrm{mL}$ ) of the leaf extracts from ten plants screened against ten bacterial strains (Continued)

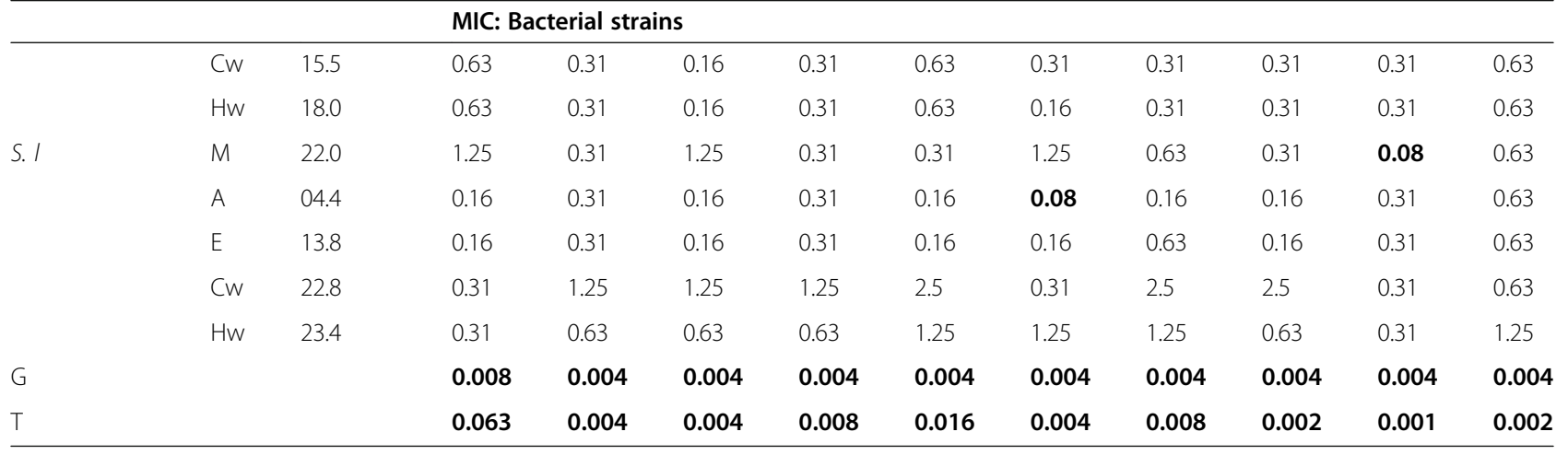

Ext extract, ND not determined, $M$ methanol, $E$ ethanol, $A$ acetone, $C w$ cold water, $H w$ hot water, B. $a$ Brachychiton acerifolium, B. $b$ Brachychiton bidwillii, $B$. $u$ Blighia unijugata, C. $m$ Carissa macrocarpa, C. $b$ Combretum bracteosum, K. $w$ Kirkia wilmsii, L. $a$ Loxostylis alata, N.a Noltea africana, P. I Protorhus longifolia, S. I Searsia leptodictya. E. $c l$ Enterobacter cloacae, E. $c$ Escherichia coli, K. $p$ Klebsiella pneumoniae, $P$. $m$ Proteus mirabilis, $P$. $a$ Pseudomonas aeruginosa, $S$. $T$ Salmonella Typhimurium, S. $m$ Stenotrophomonas maltophilia, B. $c$ Bacillus cereus, E. $f$ Enterococcus faecalis, $S$. $a$ Staphylococcus aureus, $G$ Gentamicin, $T$ Tetracycline. Values in bold indicate promising activity $(\mathrm{MIC}<0.1 \mathrm{mg} / \mathrm{mL}$ )

immune stimulation $[44,48]$ rather than direct bacterial growth inhibition.

Further testing of extracts of L. alata against Salmonella species identified very good activity against Salmonella Braenderup of the methanol crude extract of $L$. alata. This extract also had the best total activity against $S$. Braenderup. In general, the total activity of the methanol extracts was the best, hence the choice of methanol as extractant for the bulk extraction of L. alata. The ethyl acetate fraction produced using solvent-solvent fractionation had strong activity against the Salmonella serovars, and was therefore selected for isolation of active compounds.

\section{Antioxidant activity, cytotoxicity and genotoxicity}

The ABTS and DPPH assays provide a rapid and efficient in vitro evaluation of antioxidant capacity of plant phytochemicals [49]. Several plant species including $L$. alata and $P$. longifolia had promising antioxidant activity. A plant extract-based preparation with various functions including antioxidant (to prevent chemical spoilage of food) and antimicrobial (active against both pathogenic and food spoilage organisms) could be useful in the food and health industries, potentially enabling a reduction in the amount of synthetic additives used in foods [50].

A varying range of cytotoxicity of the methanol extracts was observed in this study, and the best selectivity index value of 8.05 was demonstrated by P. longifolia. A high selectivity index value suggests a good safety margin between the concentration of test sample able to inhibit the bacteria, and the concentration toxic to mammalian cells [44]. None of the extracts with good antibacterial activity were genotoxic in this study.

Table 3 Extract yield, Minimal Inhibitory Concentration (MIC) values and Total Antibacterial Activity (TAA) of the different leaf extracts of Loxostylis alata against selected Salmonella spp.

\begin{tabular}{|c|c|c|c|c|c|c|c|c|c|c|c|}
\hline \multirow[b]{2}{*}{ Extracts } & \multirow[b]{2}{*}{$\begin{array}{l}\% \\
\text { yield }\end{array}$} & \multicolumn{2}{|c|}{$\begin{array}{l}\text { Salmonella } \\
\text { Typhimurium }\end{array}$} & \multicolumn{2}{|c|}{$\begin{array}{l}\text { Salmonella } \\
\text { Braenderup }\end{array}$} & \multicolumn{2}{|c|}{ Salmonella Dublin } & \multicolumn{2}{|c|}{$\begin{array}{l}\text { Salmonella } \\
\text { Typhimurium (ATCC } \\
\text { 14028) }\end{array}$} & \multicolumn{2}{|c|}{$\begin{array}{l}\text { Salmonella Enteritidis } \\
\text { (ATCC 13076) }\end{array}$} \\
\hline & & $\begin{array}{l}\text { MIC (mg/ } \\
\mathrm{mL})\end{array}$ & $\begin{array}{l}\text { TAA (mL/ } \\
\text { g) }\end{array}$ & $\begin{array}{l}\mathrm{MIC}(\mathrm{mg} / \\
\mathrm{mL})\end{array}$ & $\begin{array}{l}\text { TAA (mL/ } \\
\text { g) }\end{array}$ & $\begin{array}{l}\mathrm{MIC}(\mathrm{mg} / \\
\mathrm{mL})\end{array}$ & $\begin{array}{l}\text { TAA (mL/ } \\
\text { g) }\end{array}$ & $\begin{array}{l}\mathrm{MIC}(\mathrm{mg} / \\
\mathrm{mL})\end{array}$ & $\begin{array}{l}\text { TAA }(\mathrm{mL} / \\
\mathrm{g})\end{array}$ & $\begin{array}{l}\text { MIC (mg/ } \\
\mathrm{mL})\end{array}$ & $\begin{array}{l}\text { TAA }(\mathrm{mL} / \\
\mathrm{g})\end{array}$ \\
\hline Methanol & 39.20 & $0.12 \pm 0.06$ & 3350.43 & $0.04 \pm 0.00$ & $10,051.28$ & $0.12 \pm 0.06$ & 3350.43 & $0.16 \pm 0.00$ & 2512.82 & $0.16 \pm 0.00$ & 2512.82 \\
\hline Acetone & 24.50 & $0.16 \pm 0.00$ & 1570.51 & $0.16 \pm 0.00$ & 1570.51 & $0.08 \pm 0.00$ & 3141.03 & $0.08 \pm 0.00$ & 3141.03 & $0.16 \pm 0.00$ & 1570.51 \\
\hline Ethanol & 35.20 & $0.16 \pm 0.00$ & 2256.41 & $0.47 \pm 0.22$ & 751.33 & $0.12 \pm 0.06$ & 3008.55 & $0.12 \pm 0.06$ & 3008.55 & $0.31 \pm 0.00$ & 1128.21 \\
\hline Cold water & 12.00 & $0.31 \pm 0.03$ & 384.62 & $0.47 \pm 0.22$ & 256.14 & $0.16 \pm 0.00$ & 769.23 & $0.16 \pm 0.00$ & 769.23 & $0.31 \pm 0.00$ & 384.62 \\
\hline Hot water & 25.80 & $0.31 \pm 0.00$ & 826.92 & $0.47 \pm 0.22$ & 550.69 & $0.23 \pm 0.11$ & 1102.56 & $0.23 \pm 0.11$ & 1102.56 & $0.31 \pm 0.00$ & 826.92 \\
\hline Gentamicin & NA & 0.008 & NA & 0.004 & NA & 0.008 & NA & 0.008 & NA & 0.008 & NA \\
\hline Ampicillin & NA & 0.004 & NA & 0.004 & NA & 0.004 & NA & 0.004 & NA & 0.004 & NA \\
\hline
\end{tabular}




\section{Average total activity}

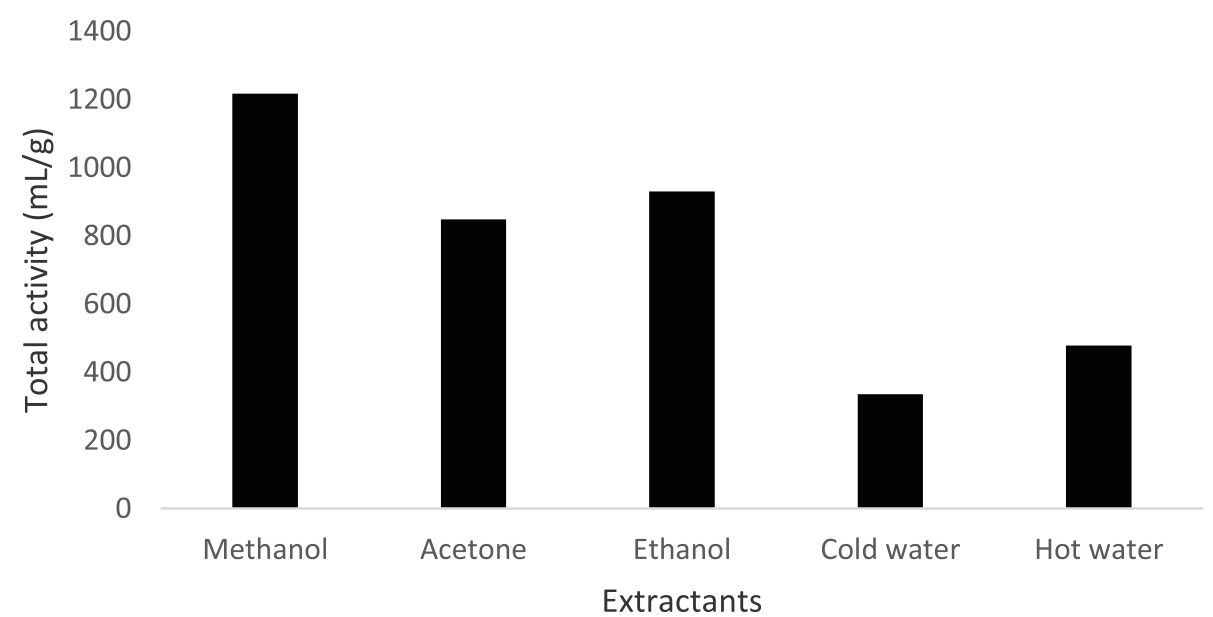

Fig. 2 Average total activity for the different extractants against screened bacteria

Isolation of compounds from L. alata with activity against Salmonella species

Two compounds were isolated and identified using mass spectrometry and NMR as delicaflavone and 5-demethyl sinensetin. The major components in the other two samples isolated were analysed using GC-MS, with benzoic acid 3, 4, 5-trihydroxy methyl ester being the primary compound identified. A search of the compound "benzoic acid, 3,4,5-trihydroxy methyl ester" on the National Center for Biotechnology Information (PubChem) Compound Database, revealed that benzoic acid, 3,4,5-trihydroxy methyl ester, is also known as methyl gallate. Sample 5 comprised mostly cetene, or 1-hexadecene, a chemical constituent of surface active agents, laundry and dish washing products [51]. Hence compound 5 was majorly a contaminant.

Loxostylis alata of the family Anacardiaceae [52] is used traditionally in South Africa for therapeutic purposes. The bark and leaves of this plant are used during childbirth [52] and, interestingly, to stimulate the immune system [53]. Several compounds such as 3-(8Zpentadecenyl) phenol (ginkgol) and 6-(8Zpentadecenyl) salicylic acid (ginkgolic acid) from the bark [54], lupeol and $\beta$-sitosterol have been isolated from $L$. alata leaves [55]. Overall, the antibacterial activity of the compounds was lower than that of the ethyl acetate fraction. The logical explanation would be that the observed activity for the crude extract or fractions occurs as a result of the synergy of the numerous constituents [44].

Biflavonoids are rare, polyphenolic molecules comprised of two identical or non-identical flavonoid units conjoined in a symmetrical or asymmetrical manner through alkyl or alkoxy-based links of varying length $[56,57]$. Biflavones have been reported in various studies to exhibit strong bioactivities, such as vasorelaxation, antifungal, antiviral, anti-inflammatory, anticancer

Table 4 Minimum inhibitory concentration (MIC) values of fractions of Loxostylis alata against Salmonella serovars

\begin{tabular}{llllll}
\hline Fractions & $\begin{array}{l}\text { MIC }(\mathbf{m g} / \mathbf{m L}) \\
\text { Salmonella } \\
\text { Typhimurium }\end{array}$ & $\begin{array}{l}\text { Salmonella } \\
\text { Braenderup }\end{array}$ & $\begin{array}{l}\text { Salmonella } \\
\text { Dublin }\end{array}$ & $\begin{array}{l}\text { Salmonella Typhimurium (ATCC } \\
\text { 14028) }\end{array}$ & $\begin{array}{l}\text { Salmonella Enteritidis (ATCC } \\
\text { 13076) }\end{array}$ \\
\hline Hexane & 0.16 & 0.16 & 0.16 & 0.16 & 0.31 \\
Chloroform & 0.16 & 0.16 & 0.31 & 0.16 & 0.31 \\
Butanol & 0.08 & 0.08 & 0.08 & 0.08 & 0.16 \\
Ethyl & 0.08 & 0.04 & 0.08 & 0.08 & 0.16 \\
acetate & & & & 0.16 & 0.31 \\
Water 1 & 0.08 & 0.31 & 0.31 & 0.31 & 1.25 \\
Water 2 & 0.31 & 0.63 & 0.63 & 0.31 & 0.008 \\
Gentamicin & 0.008 & 0.004 & 0.008 & 0.008 & 0.004 \\
Ampicillin & 0.004 & 0.004 & 0.004 & 0.004 & \\
\hline
\end{tabular}


Table 5 Antioxidant activity of methanol extracts from ten plant species

\begin{tabular}{lll}
\hline Plant species & DPPH IC $_{\mathbf{5 0}}(\boldsymbol{\mu g} / \mathbf{m L}) \pm \mathbf{S E M}$ & ABTS IC $_{\mathbf{5 0}}(\boldsymbol{\mu} \mathbf{g} / \mathbf{m L}) \pm \mathbf{S E M}$ \\
\hline B. acerifolium & $44.96 \pm 3.24^{\mathrm{d}}$ & $33.12 \pm 1.68^{\mathrm{e}}$ \\
B. bidwilli & $10.28 \pm 0.41^{\mathrm{c}}$ & $15.01 \pm 0.16^{\mathrm{d}}$ \\
B. unijugata & $4.14 \pm 0.25^{\mathrm{a}, \mathrm{b}, \mathrm{c}}$ & $3.07 \pm 0.26^{\mathrm{a}, \mathrm{b}}$ \\
C. macrocarpa & $1.13 \pm 0.12^{\mathrm{a}}$ & $3.04 \pm 0.02^{\mathrm{a}, \mathrm{b}}$ \\
C. bracteosum & $3.55 \pm 0.47^{\mathrm{a}, \mathrm{b}}$ & $6.69 \pm 0.16^{\mathrm{c}}$ \\
K. wilmsii & $4.64 \pm 0.58^{\mathrm{a}, \mathrm{b}, \mathrm{c}}$ & $2.91 \pm 0.11^{\mathrm{a}, \mathrm{b}}$ \\
L. alata & $1.89 \pm 0.09^{\mathrm{a}}$ & $1.35 \pm 0.02^{\mathrm{a}}$ \\
N. africana & $3.06 \pm 0.11^{\mathrm{a}, \mathrm{b}}$ & $5.72 \pm 0.32^{\mathrm{b}, \mathrm{c}}$ \\
P. longifolia & $5.64 \pm 0.00^{\mathrm{a}, \mathrm{b}, \mathrm{c}}$ & $2.04 \pm 0.03^{\mathrm{a}}$ \\
S. leptodictya & $7.16 \pm 1.12^{\mathrm{b}, \mathrm{c}}$ & $4.21 \pm 0.07^{\mathrm{a}, \mathrm{b}, \mathrm{c}}$ \\
Ascorbic acid $(1 \mathrm{mg} / \mathrm{ml})$ & $1.59 \pm 0.04^{\mathrm{a}}$ & $1.71 \pm 0.32^{\mathrm{a}}$ \\
Trolox (1 mg/ml) & $3.04 \pm 1.42^{\mathrm{a}, \mathrm{b}}$ & $2.40 \pm 0.87^{\mathrm{a}}$
\end{tabular}

Values with different superscript letters along each column are significantly different at $\rho<0.05$. SEM Standard error of mean

bioactivities, inhibition of tumour metastasis [57-60], and they also exhibit good antioxidant properties [61, 62]. When present in plants, these biflavonoids are considered to be the main active ingredients accounting for the treatment effect of those herbal medicines [57]. Delicaflavone is a rarely occurring biflavonoid [63], and has previously been isolated from some Selaginella species $[57,64,65]$. A previous study has also reported that delicaflavone exhibited favourable anticancer properties with anti-lung cancer effects in vitro and in vivo by inducing autophagic cell death via the Akt/mTOR/p70S6K signalling pathway [63]. Delicaflavone did not have observable side effects in a xenograft mouse model [63]. These properties, therefore, enhance the potential of the compound, or its derivatives, as a therapeutic agent.
The compound 5-demethyl sinensetin belongs to the group of flavones referred to as 'polymethoxyflavones' (PMFs) which are almost exclusively found in the citrus genus [66]. The polymethoxyflavones have been extensively studied for their anticancer potential against a number of cancer cell lines [66-69]. The antiinflammatory ability of PMFs has also been demonstrated in a previous study $[67,68]$. Results obtained from screening PMFs for cell proliferation and apoptosis induction in HL-60 cancer cell lines, showed "moderate to strong activities against the proliferation and induced apoptosis of HL-60 cell lines" [66]. A combination of inhibition effect and strong apoptosis property was obtained for 5-demethylated PMFs, which is a desirable anti-cancer property [68]. A study [69], demonstrated

Table $6 L_{50}$ and selectivity index values of methanol extracts of selected plant species against Vero monkey kidney cells

\begin{tabular}{|c|c|c|c|c|c|c|c|c|c|c|c|}
\hline \multirow[t]{2}{*}{ Plant species } & \multirow{2}{*}{$\begin{array}{l}\mathrm{LC}_{50} \\
\text { values } \\
(\mathrm{mg} / \mathrm{mL})\end{array}$} & \multicolumn{10}{|c|}{ Selectivity index values } \\
\hline & & E. cl & E. $C$ & K. $p$ & P. $m$ & P. $a$ & S. T & S. $m$ & B. $C$ & E. $f$ & S. $a$ \\
\hline B. acerifolium & $0.18 \pm 0.02$ & 0.29 & 0.29 & 0.57 & 0.29 & 0.14 & 0.29 & 0.14 & 0.07 & 0.07 & 0.07 \\
\hline B. bidwilli & $0.23 \pm 0.04$ & 0.73 & 1.45 & 0.36 & 0.36 & 0.36 & 0.73 & 0.36 & 0.09 & 0.18 & 0.36 \\
\hline B. unijugata & $0.02 \pm 0.00$ & 0.03 & 0.07 & 0.07 & 0.03 & 0.14 & 0.07 & 0.03 & 0.14 & 0.14 & 0.07 \\
\hline C. macrocarpa & $0.47 \pm 0.03$ & 0.75 & 0.38 & 0.75 & 0.38 & 3.01 & 1.50 & 0.75 & 3.01 & 6.02 & 1.50 \\
\hline C. bracteosum & $0.06 \pm 0.00$ & 0.04 & 0.18 & 0.18 & 0.09 & 0.09 & 0.18 & 0.18 & 0.09 & 0.09 & 0.04 \\
\hline K. wilmsii & $0.03 \pm 0.02$ & 0.21 & 0.21 & 0.42 & 0.21 & 0.05 & 0.21 & 0.21 & 0.11 & 0.05 & 0.85 \\
\hline L. alata & $0.20 \pm 0.03$ & 5.02 & 5.02 & 2.51 & 2.51 & 1.25 & 2.51 & 2.51 & 2.51 & 5.02 & 1.25 \\
\hline N. africana & $0.37 \pm 0.04$ & 0.30 & 0.60 & 0.60 & 0.60 & 1.19 & 1.19 & 1.19 & 0.60 & 1.19 & 0.60 \\
\hline P. longifolia & $0.31 \pm 0.01$ & 4.02 & 2.01 & 4.02 & 4.02 & 2.01 & 1.01 & 4.02 & 2.01 & 2.01 & 8.05 \\
\hline S. leptodictya & $0.24 \pm 0.03$ & 0.19 & 0.77 & 0.19 & 0.77 & 0.77 & 0.19 & 0.39 & 0.77 & 3.09 & 0.39 \\
\hline Doxorubicin & $0.007 \pm .003$ & & & & & & & & & & \\
\hline
\end{tabular}

B. acerifolium Brachychiton acerifolium, B. bidwilli Brachychiton bidwillii, B. unijugata Blighia unijugata, C. macrogaba Carissa macrocarpa, C. bracteosum Combretum bracteosum, K. wilmsii Kirkia wilmsii, L. alata Loxostylis alata, N. africana Noltea africana, P. longifolia Protorhus longifolia, S. leptodictya Searsia leptodictya, E. $c l$ Enterobacter cloacae, E. $c$ Escherichia coli, K. $p$ Klebsiella pneumoniae, $P$. $m$ Proteus mirabilis, $P$. a Pseudomonas aeruginosa, $S$. $T$ Salmonella Typhimurium, S. $m$ Stenotrophomonas maltophilia, B. c Bacillus cereus, E. $f$ Enterococcus faecalis, $S$. $a$ Staphylococcus aureus. Values in bold indicate good activity with promising SI values 
Table 7 Genotoxicity of selected methanol extracts against Salmonella Typhimurium strains (TA98 and TA100) presented as mean \pm standard error

\begin{tabular}{llll}
\hline Plant species & $\begin{array}{l}\text { Dose } \\
(\mathbf{m g} /\end{array}$ & \multicolumn{2}{l}{ Histidine + revertant colonies } \\
\cline { 3 - 4 } $\mathbf{m L})$ & 5 & $29.50 \pm 0.50$ & TA100 \\
\hline Kirkia wilmsii & 5 & $23.67 \pm 2.96$ & $145.00 \pm 2.07 \pm 2.60$ \\
& 0.5 & $23.33 \pm 0.33$ & $126.00 \pm 14.00$ \\
Loxostylis alata & 0.05 & $25.67 \pm 2.85$ & $201.50 \pm 5.50$ \\
& 0.5 & $24.67 \pm 0.88$ & $188.50 \pm 6.50$ \\
Protorhus longifolia & 5 & $23.33 \pm 0.88$ & $145.33 \pm 2.33$ \\
& 0.05 & $21.00 \pm 1.00$ & $135.50 \pm 4.50$ \\
Searsia leptodictya & 5 & $23.50 \pm 1.50$ & $142.33 \pm 8.69$ \\
& 0.05 & $24.67 \pm 2.40$ & $172.00 \pm 6.00$ \\
& 0.5 & $22.33 \pm 1.20$ & $157.00 \pm 7.00$ \\
4-NQO (+ve C) & 0.05 & $21.67 \pm 1.45$ & $109.00 \pm 16.00$ \\
10\% DMSO (-ve C) & & $316.67 \pm 7.42$ & $766.00 \pm 1.46$ \\
Water (-ve C) & & $24.67 \pm 2.40$ & $158.00 \pm 3.04$ \\
\hline
\end{tabular}

$M$ methanol extract, 4-NQO 4-nitroquinoline-1-oxide, DMSO Dimethyl sulfoxide, +ve C Positive control, -ve C Negative control

the ability of 5-demethyl sinensetin (as well as other polymethoxyflavones) to induce differentiation of normal human epidermal keratinocytes, an essential stage in the epidermal role as a barrier to water loss and microbial invasion [69]. Hence, 5-demethyl sinensetin is an appealing candidate to explore for anti-cancer activities.

Methyl gallate is a gallotannin (phenolic compound) which has been reported to be widely distributed in nature $[70,71]$. Polyphenols and flavonoids have been associated with modulating immune response [72], and hence there has been growing interest in the study of these classes of compounds. Methyl gallate has been isolated from plants used traditionally to treat gastrointestinal disorders, for example the stem bark of Entada abyssinica [73] and leaves of Pimenta racemosa [74]. Previous studies have demonstrated its bioactivities such as antioxidant [75-77], anti-inflammatory [74, 78-80], antibacterial [70, 73, 81, 82] and anti-tumor [83, 84]. Interestingly, some of the antibacterial studies on methyl gallate were able to demonstrate the mechanism of action against the pathogens. In a study on the inhibitory effect of methyl gallate on the plant-pathogenic bacterium Ralstonia solanacearum [70], scanning electron microscopy revealed that methyl gallate exerted damage to the cell wall structure of the pathogen, causing morphological changes and plasmoptysis [70]. In the same study, Fan et al. (2014) also reported that methyl gallate exhibited inhibition of protein synthesis and succinate dehydrogenase (SDH) activity in Ralstonia solanacearum. Another study worth noting investigated the role of methyl gallate in adhesion, invasion, and intracellular survival of Salmonella Typhimurium [82]. In the study by Birhanu et al. (2018), the researchers reported the ability of methyl gallate alone or in combination with sub MIC of marbofloxacin to inhibit the adhesion, invasion, motility, and intracellular survival of $S$. Typhimurium. This potential was reportedly due to the ability of methyl gallate to down-regulate quorum sensing and virulence genes in $S$. Typhimurium [82].

\section{Conclusion}

The increase in foodborne infection with its associated economic impact cannot be over-emphasized, hence the continuous search for alternative, safe and affordable therapeutics. This study investigated the in vitro<smiles>O=c1cc(-c2ccc(Oc3c(-c4ccc(O)cc4)oc4cc(O)cc(O)c4c3=O)cc2)oc2cc(O)cc(O)c12</smiles>

Delicaflavone (1)<smiles>COc1ccc(-c2cc(=O)c3c(O)c(OC)c(OC)cc3o2)cc1OC</smiles>

5- Demethyl sinensetin (2).

Fig. 3 Structure of the compounds delicaflavone (1) and '5-hydroxy-4',5',6,7-tetramethoxyflavone' (5- demethyl sinensetin) (2) isolated from Loxostylis alata 
Table 8 MIC values of isolated compounds against selected Salmonella isolates

\begin{tabular}{llll}
\hline Compounds & MIC mg/mL & Average \\
\cline { 2 - 3 } & $\begin{array}{l}\text { Salmonella Typhimurium } \\
\text { (ATCC 14028) }\end{array}$ & $\begin{array}{l}\text { Salmonella } \\
\text { Enteritidis } \\
\text { (ATCC 13076) }\end{array}$ & \\
\hline 1 & 0.250 & 0.250 & 0.250 \\
2 & 0.375 & 0.250 & 0.312 \\
3 & 0.375 & 0.375 & 0.375 \\
4 & 0.250 & 0.250 & 0.250 \\
Gentamicin & 0.008 & 0.008 & 0.008 \\
Ampicillin & 0.004 & 0.004 & 0.004 \\
\hline
\end{tabular}

antibacterial activity of selected plant species against a range of bacteria implicated in causing diarrhoea. The plant extracts tested had varying levels of activity against bacteria. This is the first report of antibacterial potential of B. acerifolium and B. bidwillii. Good antibacterial and antioxidant activity exhibited by the extracts of $L$. alata and $P$. longifolia provides support for the traditional use of these plant species as immune boosters, motivating further studies in this regard. However, cytotoxicity of extracts from B. unijugata, C. bracteosum and K. wilmsii suggests that these species should be used with caution in traditional medicine. Loxostylis alata exhibited good antibacterial activity against all bacteria tested, and had the highest selectivity index against Salmonella

Table 9 Percentage composition of the top three chemical constituents of EtOAc fraction of Loxostylis alata leaf identified by GCMS

\begin{tabular}{|c|c|c|c|c|c|}
\hline Name & $\begin{array}{l}\text { Area } \\
\%\end{array}$ & $\begin{array}{l}\text { Molecular } \\
\text { Formula }\end{array}$ & \%Similarity & CAS & Sample \\
\hline $\begin{array}{l}\text { Sample 3: } \\
\text { Benzoic acid, 3, } \\
\text { 4,5-trihydroxy- } \\
\text { methyl ester }\end{array}$ & 42.669 & $\mathrm{C}_{8} \mathrm{H}_{8} \mathrm{O}_{5}$ & 91.9 & $99-24-1$ & 1 \\
\hline $\begin{array}{l}\text { Octadecanoic } \\
\text { acid }\end{array}$ & 2.1511 & $\mathrm{C}_{18} \mathrm{H}_{36} \mathrm{O}_{2}$ & 92.1 & $57-11-4$ & 1 \\
\hline Decane & 1.6976 & $\mathrm{C}_{10} \mathrm{H}_{22}$ & 94.1 & $124-18-5$ & 1 \\
\hline $\begin{array}{l}\text { Sample 4: } \\
\text { Benzoic acid, 3, } \\
\text { 4,5-trihydroxy- } \\
\text { methyl ester }\end{array}$ & 39.133 & $\mathrm{C}_{8} \mathrm{H}_{8} \mathrm{O}_{5}$ & 91.6 & $99-24-1$ & 3 \\
\hline $\begin{array}{l}\text { Octadecanoic } \\
\text { acid }\end{array}$ & 5.7257 & $\mathrm{C}_{18} \mathrm{H}_{36} \mathrm{O}_{2}$ & 90.6 & $57-11-4$ & 3 \\
\hline $\begin{array}{l}\text { n- } \\
\text { Hexadecanoic } \\
\text { acid }\end{array}$ & 3.6108 & $\mathrm{C}_{16} \mathrm{H}_{32} \mathrm{O}_{2}$ & 91.2 & $57-10-3$ & 3 \\
\hline $\begin{array}{l}\text { Sample 5: } \\
\text { Cetene }\end{array}$ & 21.732 & $\mathrm{C}_{16} \mathrm{H}_{32}$ & 92.1 & $629-73-2$ & 5 \\
\hline Decane & 8.7951 & $\mathrm{C}_{10} \mathrm{H}_{22}$ & 90.1 & $124-18-5$ & 5 \\
\hline $\begin{array}{l}\text { 1-Penten-3-yne, } \\
\text { 2-methyl- }\end{array}$ & 6.0809 & $\mathrm{C}_{6} \mathrm{H}_{8}$ & 93.9 & $926-55-6$ & 5 \\
\hline
\end{tabular}

The most abundant constituents are highlighted in bold
Typhimurium, providing motivation for further investigation to determine if the plant could be a source of an antibacterial drug lead against Salmonella. Results obtained support previous reports of the antibacterial potential of extracts of $L$. alata. However, its antiSalmonella potential is reported for the first time in this study. This is also the first report of a biflavone (delicaflavone), polymethoxyflavone (5-demethyl sinensetin) and gallotannin (methyl gallate) isolated from L. alata. The isolated compounds did not possess exceptional anti-Salmonella potential individually, so the activity of the total extract may be attributed to synergistic properties of the plant secondary metabolites. However, these compounds may be structurally modified to enhance their activity. Combined with its good antioxidant activity and low in vitro toxicity, the antimicrobial efficacy of L. alata warrants further studies on its potential in protecting food against contamination and spoilage, as well as against diseases caused by foodborne pathogens.

\section{Abbreviations}

ABTS: 2, 2-azino-bis- (3-ethylbenzothiazoline-6-sulfonic acid); ATCC: American Type Culture Collection; CC: Column chromatography; DMSO: Dimethyl sulfoxide; DPPH: 2, 2'-diphenyl-1-picrylhydrazyl; EDTA: Ethylenediamine tetraacetic acid; GC-MS: Gas chromatography-mass spectrometry; EtOAc: Ethyl acetate; INT: lodonitrotetrazolium chloride; iNTS: invasive nontyphoidal Salmonella; MEM: Minimal Essential Medium; MeOH: Methanol; MH: Müller-Hinton; MIC: Minimum inhibitory concentration; MTT: 3-(4, 5dimethylthiazolyl-2)-2.5-diphenyltetrazolium bromide; NMR: Nuclear magnetic resonance; 4-NQO: 4-nitroquinoline-1-oxide; PMF: Polymethoxyflavone;

SI: Selectivity index; TAA: Total Antibacterial Activity; TLC: Thin layer chromatography; UPLC: Ultra Performance Liquid Chromatography; XLD: Xylose lysine deoxycholate

\section{Acknowledgments}

GC-MS, UPLC-MS and NMR analyses were conducted by Dr. Yvette Naudé, Dr. Madelien Wooding and Dr. Mamoalosi Selepe (Department of Chemistry, University of Pretoria) respectively.

\section{Authors' contributions}

DAG, MME and LM designed the study; DAG conducted the experimental work; ASA and MAA assisted with isolation of the bioactive compound; ASA helped with the antioxidant assays; BM assisted with the genotoxicity assay and SMN assisted with cytotoxicity studies; LJM and MME supervised the study. All authors have read and approved the manuscript.

\section{Funding}

The National Research Foundation (NRF), South Africa (Grant no 105993) and the South African Medical Research Council (SIR) are acknowledged for providing research funding to $L M$, which was used for collection of plant materials, analysis, and interpretation of data. The NRF is thanked for awarding a PhD Scholarship to DAG and a Postdoctoral Fellowship to BM. The University of Pretoria is thanked for Postdoctoral Fellowships awarded to ASA and MAA.

Availability of data and materials Not applicable.

\section{Declarations}

Ethics approval and consent to participate

Not applicable.

Consent for publication

All authors have given their consent for publication. 


\section{Competing interests}

None.

\section{Author details}

'Phytomedicine Programme, Department of Paraclinical Sciences, University of Pretoria, Private Bag X04, Onderstepoort 0110, Pretoria, South Africa. ${ }^{2}$ Regional Laboratory for Animal Influenzas and other Transboundary Animal Diseases, National Veterinary Research Institute, PMB 01, Vom, Plateau State, Nigeria. ${ }^{3}$ Department of Food Science and Technology, Faculty of Agriculture, University of Khartoum, 13314 Khartoum North, Sudan. ${ }^{4}$ Department of Medical Microbiology, Faculty of Health Sciences, University of Pretoria, PO Box X323, Arcadia 0007, Pretoria, South Africa. ${ }^{5}$ National Health Laboratory Service, Tshwane Academic Division, Pretoria, South Africa.

\section{Received: 14 October 2020 Accepted: 29 March 2021} Published online: 13 April 2021

\section{References}

1. Negi PS. Plant extracts for the control of bacterial growth: efficacy, stability and safety issues for food application. Int J Food Microbiol. 2012;156(1):717. https://doi.org/10.1016/j.ijfoodmicro.2012.03.006.

2. WHO. Food safety fact sheet 2018. updated 31 October 2017. Available from: http://www.who.int/news-room/fact-sheets/detail/food-safety.

3. Carrasco E, Morales-Rueda A, García-Gimeno RM. Cross-contamination and recontamination by Salmonella in foods: a review. Food Res Int. 2012;45(2): 545-56. https://doi.org/10.1016/j.foodres.2011.11.004.

4. Boyle EC, Bishop JL, Grassl GA, Finlay BB. Salmonella: from pathogenesis to therapeutics. J Bacteriol. 2007;189(5):1489-95. https://doi.org/10.1128/JB.01 730-06.

5. Mahlangu ZP, Botha FS, Madoroba E, Chokoe K, Elgorashi EE. Antimicrobial activity of Albizia gummifera (J.F.Gmel.) C.A.Sm leaf extracts against four Salmonella serovars. S Afr J Bot. 2017;108:132-6.

6. Barua H, Biswas PK, Olsen KEP, Shil SK, Christensen JP. Molecular characterization of motile serovars of Salmonella enterica from breeder and commercial broiler poultry farms in Bangladesh. PLoS One. 2013;8(3):e57811. https://doi.org/10.1371/journal.pone.0057811.

7. Feasey NA, Dougan G, Kingsley RA, Heyderman RS, Gordon MA. Invasive non-typhoidal salmonella disease: an emerging and neglected tropical disease in Africa. Lancet. 2012;379(9835):2489-99. https://doi.org/10.1016/ S0140-6736(11)61752-2.

8. Feasey NA, Hadfield J, Keddy KH, Dallman TJ, Jacobs J, Deng X, et al. Distinct Salmonella Enteritidis lineages associated with enterocolitis in highincome settings and invasive disease in low-income settings. Nat Genet. 2016;48(10):1211-7.

9. Bruun T, Sørensen G, Forshell LP, Jensen T, Nygård K, Kapperud G, et al. An outbreak of salmonella typhimurium infections in Denmark, Norway and Sweden, 2008. Euro Surveill (Online Edition). 2009;14(10):19147.

10. Phillips I, Casewell M, Cox T, De Groot B, Friis C, Jones R, et al. Does the use of antibiotics in food animals pose a risk to human health? A critical review of published data. J Antimicrob Chemother. 2004;53(1):28-52. https://doi. org/10.1093/jac/dkg483.

11. Sarmah AK, Meyer MT, Boxall ABA. A global perspective on the use, sales, exposure pathways, occurrence, fate and effects of veterinary antibiotics (VAs) in the environment. Chemosphere. 2006;65(5):725-59. https://doi.org/1 0.1016/j.chemosphere.2006.03.026.

12. Kuppusamy S, Kakarla D, Venkateswarlu K, Megharaj M, Yoon Y-E, Lee YB. Veterinary antibiotics (VAs) contamination as a global agro-ecological issue: a critical view. Agric Ecosyst Environ. 2018;257:47-59. https://doi.org/10.101 6/j.agee.2018.01.026.

13. Cooke FJ, Wain J, Mastroeni P, Maskell D. Antibiotic resistance in Salmonella infections. In: Salmonella infections: clinical, immunological and molecular aspects; 2006. p. 25-56. https://doi.org/10.1017/CBO9780511525360.003.

14. Ventola CL. The antibiotic resistance crisis: part 1: causes and threats. Pharm Ther. 2015;40(4):277-83.

15. Threlfall EJ. Salmonella. In: Heggenhougen HK, editor. International encyclopedia of public health. Oxford: Academic Press; 2008. p. 639-47. https://doi.org/10.1016/B978-012373960-5.00613-4.

16. WHO. Antibiotic resistance factsheet 2018. updated 5 February 2018. Available from: http://www.who.int/news-room/fact-sheets/detail/antibioticresistance.
17. Hemaiswarya S, Kruthiventi AK, Doble M. Synergism between natural products and antibiotics against infectious diseases. Phytomedicine. 2008; 15(8):639-52. https://doi.org/10.1016/j.phymed.2008.06.008.

18. Koma OS, Fatokun OA, Theophilus OA. Phytochemical screening and in vitro antimicrobial activity of Waltheria Indica Linn leaf extracts. Biomed Sci. 2017;3(5):86. https://doi.org/10.11648/j.bs.20170305.11.

19. Spellberg B, Powers JH, Brass EP, Miller LG, Edwards JJE. Trends in antimicrobial drug development: implications for the future. Clin Infect Dis. 2004;38(9):1279-86. https://doi.org/10.1086/420937.

20. Eloff JN, McGaw L. Using African plant biodiversity to combat microbial infections. In: Novel Plant Bioresources: Applications in Food, Medicine and Cosmetics; 2014. p. 163-73. https://doi.org/10.1002/9781118460566.ch12.

21. Luepke KH, Suda KJ, Boucher H, Russo RL, Bonney MW, Hunt TD, et al. Past, present, and future of antibacterial economics: increasing bacterial resistance, limited antibiotic pipeline, and societal implications. Pharmacotherapy. 2017;37(1):71-84. https://doi.org/10.1002/phar.1868.

22. Pye CR, Bertin MJ, Lokey RS, Gerwick WH, Linington RG. Retrospective analysis of natural products provides insights for future discovery trends. Proc Natl Acad Sci. 2017;114(22):5601-6. https://doi.org/10.1073/pnas.1614 680114

23. Fromage $\mathrm{G}$. Antibiotic resistance: an exploration of its causes and management strategies. J Aesthet Nurs. 2018;7(1):18-23. https://doi.org/1 0.12968/joan.2018.7.1.18.

24. Newman DJ, Cragg GM, Snader KM. The influence of natural products upon drug discovery. Nat Prod Rep. 2000;17(3):215-34. https://doi.org/10.1039/a 902202c.

25. Cragg GM, Newman DJ. Natural products: a continuing source of novel drug leads. Biochim Biophys Acta Gen Subj. 2013;1830(6):3670-95.

26. Newman DJ, Cragg GM. Natural products as sources of new drugs from 1981 to 2014. J Nat Prod. 2016;79(3):629-61. https://doi.org/10.1021/acs.jna tprod.5b01055.

27. Ripa FA, Haque M, Imran-UI-Haque M. In vitro antimicrobial, cytotoxic and antioxidant activity of flower extract of Saccharum spontaneum Linn. Eur J Sci Res. 2009;30(3):478-83.

28. Elisha IL, Botha FS, McGaw LJ, Eloff JN. The antibacterial activity of extracts of nine plant species with good activity against Escherichia coli against five other bacteria and cytotoxicity of extracts. BMC Complement Altern Med. 2017;17(1):133. https://doi.org/10.1186/s12906-017-1645-z.

29. Van Wyk B-E, Wink M. Medicinal plants of the world: an illustrated scientific guide to important medicinal plants and their uses: timber press; 2004.

30. Bozin B, Mimica-Dukic N, Samojlik I, Goran A, Igic R. Phenolics as antioxidants in garlic (Allium sativum L., Alliaceae). Food Chem. 2008;111(4): 925-9. https://doi.org/10.1016/j.foodchem.2008.04.071.

31. Kumari P, Khatkar BS. Assessment of total polyphenols, antioxidants and antimicrobial properties of aonla varieties. J Food Sci Technol. 2016;53(7): 3093-103. https://doi.org/10.1007/s13197-016-2282-0.

32. Pauw E, Eloff JN. Which tree orders in southern Africa have the highest antimicrobial activity and selectivity against bacterial and fungal pathogens of animals? BMC Complement Altern Med. 2014;14(1):1.

33. Papuc C, Goran GV, Predescu CN, Nicorescu V, Stefan G. Plant polyphenols as antioxidant and antibacterial agents for shelf-life extension of meat and meat products: classification, structures, sources, and action mechanisms. Compr Rev Food Sci Food Saf. 2017;16(6):1243-68. https://doi.org/10.1111/1 541-4337.12298.

34. Takó M, Kerekes EB, Zambrano C, Kotogán A, Papp T, Krisch J, et al. Plant Phenolics and phenolic-enriched extracts as antimicrobial agents against food-contaminating microorganisms. Antioxidants. 2020;9(2):165. https://doi. org/10.3390/antiox9020165.

35. Jambalang AR, Buys EM, Botha FS. Bacterial species from retailed poultry eggs in Tshwane, South Africa: implication for consumers. S Afr J Sci. 2017; 113(11-12):1-7. https://doi.org/10.17159/sajs.2017/20160232.

36. Eloff JN. A sensitive and quick microplate method to determine the minimal inhibitory concentration of plant extracts for bacteria. Planta Med. 1998;64(8):711-3. https://doi.org/10.1055/s-2006-957563.

37. Eloff JN. On expressing the antibacterial activity of plant extracts--a small first step in applying scientific knowledge to rural primary health care. S Afr J Sci. 2000;96(3):116-8.

38. Dzoyem JP, McGaw LJ, Eloff JN. In vitro antibacterial, antioxidant and cytotoxic activity of acetone leaf extracts of nine under-investigated Fabaceae tree species leads to potentially useful extracts in animal health and productivity. BMC Complement Altern Med. 2014;14(1):1. 
39. Re R, Pellegrini N, Proteggente A, Pannala A, Yang M, Rice-Evans C. Antioxidant activity applying an improved ABTS radical cation decolorization assay. Free Radic Biol Med. 1999;26(9-10):1231-7. https://doi. org/10.1016/S0891-5849(98)00315-3.

40. Brand-Williams W, Cuvelier M-E, Berset C. Use of a free radical method to evaluate antioxidant activity. LWT-Food Sci Technol. 1995;28(1):25-30. https://doi.org/10.1016/S0023-6438(95)80008-5.

41. Mosmann T. Rapid colorimetric assay for cellular growth and survival: application to proliferation and cytotoxicity assays. J Immunol Methods. 1983;65(1-2):55-63. https://doi.org/10.1016/0022-1759(83)90303-4.

42. McGaw LJ, Steenkamp V, Eloff JN. Evaluation of Athrixia bush tea for cytotoxicity, antioxidant activity, caffeine content and presence of pyrrolizidine alkaloids. J Ethnopharmacol. 2007;110(1):16-22. https://doi. org/10.1016/j.jep.2006.08.029

43. Verschaeve L, Van Staden J. Mutagenic and antimutagenic properties of extracts from south African traditional medicinal plants. J Ethnopharmacol. 2008;119(3):575-87. https://doi.org/10.1016/j.jep.2008.06.007.

44. Madikizela B, McGaw LJ. Scientific rationale for traditional use of plants to treat tuberculosis in the eastern region of the OR Tambo district, South Africa. J Ethnopharmacol. 2018;224:250-60. https://doi.org/10.1016/j.jep.201 8.06.002.

45. Efferth T, Kuete V. Cameroonian medicinal plants: pharmacology and derived natural products. Front Pharmacol. 2010;1:123.

46. Holetz FB, Pessini GL, Sanches NR, Cortez DAG, Nakamura CV, Dias Filho BP. Screening of some plants used in the Brazilian folk medicine for the treatment of infectious diseases. Mem Inst Oswaldo Cruz. 2002;97(7):102731. https://doi.org/10.1590/S0074-02762002000700017.

47. Suleiman MM, McGaw LJ, Naidoo V, Eloff JN. Evaluation of several tree species for activity against the animal fungal pathogen Aspergillus fumigatus. S Afr J Bot. 2010;76(1):64-71. https://doi.org/10.1016/j.sajb.2009. 07.001.

48. Rios JL, Recio MC. Medicinal plants and antimicrobial activity. J Ethnopharmacol. 2005;100(1):80-4. https://doi.org/10.1016/j.jep.2005.04.025.

49. Ahmed AS, McGaw LJ, Elgorashi EE, Naidoo V, Eloff JN. Polarity of extracts and fractions of four Combretum (Combretaceae) species used to treat infections and gastrointestinal disorders in southern African traditiona medicine has a major effect on different relevant in vitro activities. $J$ Ethnopharmacol. 2014;154(2):339-50. https://doi.org/10.1016/j.jep.2014.03.03 0.

50. Gutiérrez D, Delgado S, Vázquez-Sánchez D, Martínez B, Cabo ML, Rodríguez A, et al. Incidence of Staphylococcus aureus and analysis of bacterialassociated communities on food industry surfaces. Appl Environ Microbiol. 2012;78(24):8547-54. AEM. 02045-12.

51. National Center for Biotechnology Information. PubChem Compound Database; 1-Hexadecene: National Center for Biotechnology Information; 2005. Available from: https://pubchem.ncbi.nlm.nih.gov/compound/12395. Cited Dec 9, 2018

52. Pooley E. Complete field guide to trees of Natal. Zululand \& Transkei: Natal Flora Publications Trust; 1993.

53. Pell SK. Molecular systematics of the cashew family (Anacardiaceae); 2004.

54. Drewes SE, Horn MM, Mabaso NJ. Loxostylis alata and Smodingium argutum-a case of phytochemical bedfellows? S Afr J Bot. 1998;64(2):128-9. https://doi.org/10.1016/S0254-6299(15)30846-2.

55. Suleiman MM. The in vitro and in vivo biological activities of antifungal compounds isolated from Loxostylis alata ASprengex Rchbleaf extracts: University of Pretoria Repository; 2009.

56. Aravind SG, Arimboor R, Rangan M, Madhavan SN, Arumughan C. Semipreparative HPLC preparation and HPTLC quantification of tetrahydroamentoflavone as marker in Semecarpus anacardium and its polyherbal formulations. J Pharm Biomed Anal. 2008;48(3):808-13. https:// doi.org/10.1016/j.jpba.2008.08.008

57. Li S, Yao H, Zhao M, Li Y, Huang L, Lin X. Determination of seven biflavones of Selaginella doederleinii by high performance liquid chromatography. Anal Lett. 2013;46(18):2835-45. https://doi.org/10.1080/00032719.2013.83142 6.

58. Kang DG, Yin $\mathrm{MH}$, Oh H, Lee $\mathrm{DH}$, Lee HS. Vasorelaxation by amentoflavone isolated from Selaginella tamariscina. Planta Med. 2004;70(08):718-22. https://doi.org/10.1055/s-2004-827201

59. Jung HJ, Sung WS, Yeo S-H, Kim HS, Lee I-S, Woo E-R, et al. Antifungal effect of amentoflavone derived fromSelaginella tamariscina. Arch Pharm Res. 2006;29(9):746-51. https://doi.org/10.1007/BF02974074.
60. Lee N-Y, Min H-Y, Lee J, Nam J-W, Lee Y-J, Han A-R, et al. Identification of a new cytotoxic biflavanone from Selaginella doederleinii. Chem Pharm Bull. 2008;56(9):1360-1. https://doi.org/10.1248/cpb.56.1360.

61. Russo A, Acquaviva R, Campisi A, Sorrenti V, Di Giacomo C, Virgata G, et al. Bioflavonoids as antiradicals, antioxidants and DNA cleavage protectors. Cell Biol Toxicol. 2000;16(2):91-8. https://doi.org/10.1023/A:1007685909018.

62. Waterman MJ, Nugraha AS, Hendra R, Ball GE, Robinson SA, Keller PA. Antarctic Moss Biflavonoids show high antioxidant and ultraviolet-screening activity. J Nat Prod. 2017;80(8):2224-31. https://doi.org/10.1021/acs.jnatprod. 7 b00085.

63. Sui Y, Yao H, Li S, Jin L, Shi P, Li Z, et al. Delicaflavone induces autophagic cell death in lung cancer via Akt/mTOR/p70S6K signaling pathway. J Mol Med. 2017;95(3):311-22. https://doi.org/10.1007/s00109-016-1487-z.

64. Lin L-C, Chou C-J. Three new biflavonoids from Selaginella delicatula. Chin Pharm J. 2000:52(4):211-8.

65. Chen B, Wang X, Zou Y, Chen W, Wang G, Yao W, et al. Simultaneous quantification of five biflavonoids in rat plasma by LC-ESI-MS/MS and its application to a comparatively pharmacokinetic study of Selaginella doederleinii Hieron extract in rats. J Pharm Biomed Anal. 2018;149:80-8. https://doi.org/10.1016/j.jpba.2017.10.028.

66. Li S, Pan M-H, Lai C-S, Lo C-Y, Dushenkov S, Ho C-T. Isolation and syntheses of polymethoxyflavones and hydroxylated polymethoxyflavones as inhibitors of HL-60 cell lines. Bioorg Med Chem. 2007;15(10):3381-9. https:// doi.org/10.1016/j.bmc.2007.03.021.

67. Murakami A, Nakamura Y, Torikai K, Tanaka T, Koshiba T, Koshimizu K, et al. Inhibitory effect of citrus nobiletin on phorbol ester-induced skin inflammation, oxidative stress, and tumor promotion in mice. Cancer Res. 2000;60(18):5059-66.

68. Lin N, Sato T, Takayama Y, Mimaki Y, Sashida Y, Yano M, et al. Novel antiinflammatory actions of nobiletin, a citrus polymethoxy flavonoid, on human synovial fibroblasts and mouse macrophages. Biochem Pharmacol. 2003;65(12):2065-71. https://doi.org/10.1016/S0006-2952(03)00203-X.

69. Ohguchi K, linuma M, Nozawa Y, Ito M. Nobiletin, a polymethoxylated flavone from citrus peels, induces differentiation of normal human epidermal keratinocytes. J Med Plants Res. 2014;8(33):1060-4.

70. Fan W-W, Yuan G-Q, Li Q-Q, Lin W. Antibacterial mechanisms of methyl gallate against Ralstonia solanacearum. Australas Plant Pathol. 2014;43(1):17. https://doi.org/10.1007/s13313-013-0234-y.

71. Anzoise ML, Basso AR, Del Mauro JS, Carranza A, Ordieres GL, Gorzalczany S. Potential usefulness of methyl gallate in the treatment of experimental colitis. Inflammopharmacology. 2018;26(3):839-49.

72. Somani SJ, Modi KP, Majumdar AS, Sadarani BN. Phytochemicals and their potential usefulness in inflammatory bowel disease. Phytother Res. 2015; 29(3):339-50. https://doi.org/10.1002/ptr.5271.

73. Teke GN, Lunga PK, Wabo HK, Kuiate J-R, Vilarem G, Giacinti G, et al. Antimicrobial and antioxidant properties of methanol extract, fractions and compounds from the stem bark of Entada abyssinica Stend ex A. Satabie. BMC Complement Altern Med. 2011;11(1):57.

74. Moharram FA-e, Al-Gendy AA, El-Shenawy SM, Ibrahim BM, Zarka MA. Phenolic profile, anti-inflammatory, antinociceptive, anti-ulcerogenic and hepatoprotective activities of Pimenta racemosa leaves. BMC Complement Altern Med. 2018;18(1):208

75. Niehaus A, Apalata T, Coovadia Y, Smith A, Moodley P. An Outbreak of Foodborne Salmonellosis in Rural KwaZulu-Natal, South Africa; 2011. p. 6937.

76. Asnaashari M, Farhoosh R, Sharif A. Antioxidant activity of gallic acid and methyl gallate in triacylglycerols of Kilka fish oil and its oil-in-water emulsion. Food Chem. 2014;159:439-44. https://doi.org/10.1016/j. foodchem.2014.03.038

77. Claudia D, Mario C-H, Arturo N, Omar Noel M-C, Antonio N, Teresa R, et al. Phenolic Compounds in Organic and Aqueous Extracts from Acacia farnesiana Pods Analyzed by ULPS-ESI-Q-oa/TOF-MS. In Vitro Antioxidant Activity and Anti-Inflammatory Response in CD-1 Mice. Molecules. 2018; 23(9):2386.

78. Chae H-S, Kang O-H, Choi J-G, Oh Y-C, Lee Y-S, Brice O-O, et al. Methyl gallate inhibits the production of interleukin- 6 and nitric oxide via downregulation of extracellular-signal regulated protein kinase in RAW 264.7 cells. Am J Chin Med. 2010;38(05):973-83. https://doi.org/10.1142/S0192415X1 0008391.

79. Correa LB, Pádua TA, Seito LN, Costa TEMM, Silva MA, Candéa ALP, et al. Anti-inflammatory effect of methyl gallate on experimental arthritis: 
inhibition of neutrophil recruitment, production of inflammatory mediators, and activation of macrophages. J Nat Prod. 2016;79(6):1554-66. https://doi. org/10.1021/acs.jnatprod.5b01115

80. Reyes A, Kim D, Simborio H, Hop H, Arayan L, Min W, et al. Methyl gallate limits infection in mice challenged with B rucella abortus while enhancing the inflammatory response. J Appl Microbiol. 2016;120(3):552-9. https://doi. org/10.1111/jam.13019.

81. Kang M-S, Oh J-S, Kang I-C, Hong S-J, Choi C-H. Inhibitory effect of methyl gallate and gallic acid on oral bacteria. J Microbiol. 2008;46(6):744-50. https://doi.org/10.1007/s12275-008-0235-7.

82. Birhanu BT, Park N-H, Lee S-J, Hossain MA, Park S-C. Inhibition of Salmonella Typhimurium adhesion, invasion, and intracellular survival via treatment with methyl gallate alone and in combination with marbofloxacin. Vet Res. 2018:49(1):101. https://doi.org/10.1186/s13567-018-0597-8.

83. Lee S-H, Kim JK, Kim DW, Hwang HS, Eum WS, Park J, et al. Antitumor activity of methyl gallate by inhibition of focal adhesion formation and Akt phosphorylation in glioma cells. Biochim Biophys Acta Gen Subj. 2013; 1830(8):4017-29.

84. Chaudhuri D, Ghate NB, Singh SS, Mandal N. Methyl gallate isolated from Spondias pinnata exhibits anticancer activity against human glioblastoma by induction of apoptosis and sustained extracellular signal-regulated kinase 1/2 activation. Pharmacogn Mag. 2015;11(42):269-76. https://doi.org/10.41 03/0973-1296.153078.

\section{Publisher's Note}

Springer Nature remains neutral with regard to jurisdictional claims in published maps and institutional affiliations.

Ready to submit your research? Choose BMC and benefit from:

- fast, convenient online submission

- thorough peer review by experienced researchers in your field

- rapid publication on acceptance

- support for research data, including large and complex data types

- gold Open Access which fosters wider collaboration and increased citations

- maximum visibility for your research: over $100 \mathrm{M}$ website views per year

At $\mathrm{BMC}$, research is always in progress.

Learn more biomedcentral.com/submissions 